\title{
Evaluation of Tuberose (Polianthes tuberosa) Cultivars for Semi-arid Tropic Condition Similar to Tiruchirappalli, Tamilnadu, India
}

\author{
A. D. Ashok*, K. Kayalvizhi and J. Ravivarman \\ Institute of Agriculture, Tamil Nadu Agricultural University, Kumulur - 621712, Trichy, India \\ *Corresponding author
}

\section{A B S T R A C T}

K e y w o r d s
$\begin{aligned} & \text { Tuberose, Cultivars, } \\ & \text { Semi-arid, Yield } \\ & \text { analysis, Evaluation }\end{aligned}$
Article Info
$\begin{aligned} & \text { Accepted: } \\ & \text { 20 June } 2020 \\ & \text { Available Online: } \\ & \text { 10 July } 2020\end{aligned}$

\section{Introduction}

Tuberose (Polianthes tuberosa) is one of the most important cut flowers in India. It is an ornamental bulbous plant, native to Mexico and belongs to the family Amaryllidaceae. There are only two types of tuberose (Single and Double) cultivated in the world. As a loose flower, they are in great demand for making garlands and veni in Southern India. It is being used for worshipping, offerings in religious functions and auspicious days (Krishnamoorthy, 2014). The flowers are also used for the extraction of valuable essential oil, which is having a greater export demand (Martolia, 2010). It is cultivated on a large scale in Tamil Nadu, Karnataka, West Bengal, and Maharastra. To a lesser extent, it is also grown in Andhra Pradesh, Haryana, Delhi, Uttar Pradesh and Punjab. At present, throughout India, several cultivars and local varieties are available in tuberose. Varieties which perform well in one region may not do well in other regions of varying climatic conditions (Kamble et al., 2004). Hence, location specific evaluation of varieties will help the growers to select the most suitable and high yielding variety for that particular region. Critical assessment of germplasm also helps in selecting parents for breeding programmes to improve the yield and quality of the flowers. Hence, the present investigation was conducted to study the relative performance of the five loose flower 
cultivars for semi-arid tropic condition similar to Tiruchirappalli, Tamilnadu.

\section{Materials and Methods}

The experiment was conducted at Institute of Agriculture, Tamil Nadu Agricultural University, Kumulur, Tiruchirappalli District, Tamilnadu. A total of five tuberose genotypes (single type) via., Calcutta single, Hyderabad single, Phule Rajani, Prajwal and Shringar were evaluated for vegetative growth, flowering and yield in a randomized complete block design with four replications. Before initiating the experiment, the soil was brought to a fine tilt with four deep ploughing. Weeds, stubbles, roots etc., were removed. Medium sized bulbs (3.0-3.5 cm diameter) of about 25 grams were planted at a spacing of $45 \mathrm{~m}$ x 20 $\mathrm{m}$ which accommodates 11 plants per $\mathrm{m}^{2}$.The cultural practices were adopted as per the recommendations of crop production guide of Horticultural Crops, Tamil Nadu Agricultural University to raise the crop. Five random plants were selected for recording various observations viz., plant height $(\mathrm{cm})$, days for spike emergence, number of spikes per plant, number of florets per spike, single flower weight $(\mathrm{g})$, yield per plant $(\mathrm{g})$ and yield per hectare ( $\mathrm{t} / \mathrm{ha})$. The estimates of mean, variance and standard error were done as per Panse and Sukhatme (1967).

\section{Results and Discussion}

The mean performance of the cultivars on various parameters were shown in table 1 . The highest plant height was recorded in Prajwal $(108.75 \mathrm{~cm})$ followed by Phule Rajani $(88.50 \mathrm{~cm})$ and Shringar $(86.75 \mathrm{~cm})$. On observing the reproductive characters, Prajwal was significantly earliest in days for spike emergence (80 days) among the cultivars which is in line with the findings of Patil et al., (2009) and Ranchana et al., (2013). Cultivar Prajwal recorded maximum number of spike per plant (4.57), maximum number of florets per spike (48.00) and maximum single flower weight $(1.59 \mathrm{~g})$. Next to Prajwal, Shringar performed well with number of spike per plant (3.83), number of florets per spike (43.00) and single flower weight $(1.23 \mathrm{~g})$ recorded. The performances of Prajwal and Shringar recorded were similar to the findings of Ranchana et al., (2013).

Table.1 Performance of tuberose genotypes for yield

\begin{tabular}{|l|c|c|c|c|c|c|c|}
\hline \multicolumn{1}{|c|}{ Varieties } & $\begin{array}{c}\text { Plant } \\
\text { height } \\
\text { (cm) }\end{array}$ & $\begin{array}{c}\text { Days for } \\
\text { spike } \\
\text { emergence }\end{array}$ & $\begin{array}{c}\text { No. of } \\
\text { spike per } \\
\text { plant }\end{array}$ & $\begin{array}{c}\text { No. of } \\
\text { floret per } \\
\text { spike }\end{array}$ & $\begin{array}{c}\text { Single } \\
\text { flower } \\
\text { weight }(\mathbf{g})\end{array}$ & $\begin{array}{c}\text { Yield per } \\
\text { plant (g) }\end{array}$ & $\begin{array}{c}\text { Yield per } \\
\text { hectare } \\
\text { (t/ha) }\end{array}$ \\
\hline Calcutta single & 73.59 & 96.00 & 3.01 & 33.00 & 1.17 & 56.98 & 6.33 \\
\hline $\begin{array}{l}\text { Hyderabad } \\
\text { single }\end{array}$ & 75.80 & 92.00 & 3.33 & 44.00 & 0.76 & 61.20 & 6.80 \\
\hline Phule Rajani & 88.50 & 87.00 & 3.28 & 41.00 & 1.18 & 91.35 & 10.15 \\
\hline Prajwal & 108.75 & 80.00 & 4.57 & 48.00 & 1.59 & 99.00 & 11.00 \\
\hline Shringar & 86.75 & 85.00 & 3.83 & 43.00 & 1.23 & 95.85 & 10.65 \\
\hline Mean & 86.68 & 88.00 & 3.60 & 41.80 & 1.19 & 80.88 & 8.99 \\
\hline SEd & 1.80 & 0.80 & 0.08 & 0.72 & 0.03 & 2.60 & 0.29 \\
\hline CD & 3.93 & 1.75 & 0.17 & 1.56 & 0.07 & 5.66 & 0.63 \\
\hline
\end{tabular}

On analysing yield parameters, Prajwal and Shringar recorded maximum yield per plant (99.00 $\mathrm{g}$ and 95.85) as well as maximum yield per hectare (11.00 t/ha and $10.65 \mathrm{t} / \mathrm{ha})$ respectively. Calcutta single recorded the very low yield per plant (56.98 g) and yield per 
hectare (6.33 t/ha) among the cutivars evaluated. From the study we understood that, days for first flowering, number of spike per plant, number of florets per spike and single flower weight are the parameters have direct influence on the yield. This was in line with findings of Ranchana et al., (2015) that the characters viz., weight of florets per spike, days to spike emergence had significant positive correlation co-efficients and positive direct effects on yield. The weight of florets per spike might be due to the increased number of florets per spike (Ranchana et al., 2013). The highest yield registered by Prajwal might be due to its capacity to produce more number of florets per spike and weight of florets per spike (Ranchana et al., 2013). Similar performances of Prajwal were observed by Krishnamoorthy (2014). From this experiment, we can conclude that, Prajwal and Shringar cultivars yields comparatively more under semi-arid tropic condition similar to Tiruchirappalli, Tamilnadu.

In conclusion from this experiment, we can conclude that, Prajwal and Shringar cultivars yields comparatively more under semi-arid tropic condition similar to Tiruchirappalli, Tamilnadu.

\section{References}

Kamble, B.S., B.S. Reddy, R.T.Patil and Kulkarni, B.S. 2004. Performance of gladiolous (Gladiolous hybridus Hort.) cultivars for flowering and flower quality.
Journal of Ornamental Horticulture 7: 5160.

Krishnamoorthy, V., 2014. Assessment of tuberose (Polianthes tuberosa) varieties for growth and yield characters. The Asian J Hort. 9(2): 515-517.

Martolia, K., 2010. Varietal evaluation of tuberose (Polianthes tuberosa L.) for flowering, concrete and absolute content under tarai conditions. Ph.D. Thesis. Govind Ballabh Pant University of Agriculture \& Technology. Pantnagar (U.S. Nagar), Uttarakhand, India: 162.

Panse, V.G., and Sukhutme, P.V. 1967. Statistical methods for agricultural workers (2nd Edn.). Indian Council of Agricultural Research, New Delhi: 381.

Patil, V.S., P.M. Munikrishnappa and Tirakannanavar S. 2009. Performance of growth and yield of different genotypes of tuberose under transitional tract of north Karnataka. Journal of Ecobiology. 24: 327-333.

Ranchana, P., M. Kannan and Jawaharlal M. 2013. The Assessment of Genetic Parameters: Yield, Quality Traits and Performance of Single Genotypes, of Tuberose (Polianthes tuberosa). Adv Crop Sci Tech, 1: 111.

Ranchana, P., M. Kannan, and Jawaharlal, M. 2015. Correlation and path analysis studies in double type tuberose. Asian J. Hort., 10(1): 113-117.

Trueblood, E.W.E. 1973. Omixochitl the tuberose (Polianthes tuberosa). Econ. Bot. 27: 157-173.

\section{How to cite this article:}

Ashok, A. D., K. Kayalvizhi and Ravivarman, J. 2020. Evaluation of Tuberose (Polianthes tuberosa) Cultivars for Semi-arid Tropic Condition Similar to Tiruchirappalli, Tamilnadu, India. Int.J.Curr.Microbiol.App.Sci. 9(07): 2412-2414.

doi: https://doi.org/10.20546/ijcmas.2020.907.282 